\title{
Taking stock of the first 133 MERS coronavirus cases globally - Is the epidemic changing?
}

P M Penttinen (Pasi.Penttinen@ecdc.europa.eu) ${ }^{1}$, K Kaasik-Aaslav ${ }^{1}$, A Friaux ${ }^{1}$, A Donachie ${ }^{1}$, B Sudre ${ }^{1}$, A J Amato-Gauci ${ }^{1}$, Z A Memish', , D Coulombier $^{1}$

1. European Centre for Disease Prevention and Control (ECDC), Stockholm, Sweden

2. Ministry of Health, Riyadh, Kingdom of Saudi Arabia

3. Alfaisal University, Riyadh, Kingdom of Saudi Arabia

Citation style for this article:

Penttinen PM, Kaasik-Aaslav K, Friaux A, Donachie A, Sudre B, Amato-Gauci Al, Memish ZA, Coulombier D. Taking stock of the first 133 MERS coronavirus cases

globally - Is the epidemic changing?. Euro Surveill. 2013;18(39):pii=20596. Available online: http://www.eurosurveillance.org/ViewArticle.aspx?Articleld=20596

Article submitted on 12 September 2013 / published on 26 September 2013

Since June 2012, 133 Middle East respiratory syndrome coronavirus (MERS-CoV) cases have been identified in nine countries. Two time periods in $\mathbf{2 0 1 3}$ were compared to identify changes in the epidemiology. The case-fatality risk (CFR) is $45 \%$ and is decreasing. Men have a higher CFR (52\%) and are over-represented among cases. Thirteen out of 14 known primary cases died. The sex-ratio is more balanced in the latter period. Nosocomial transmission was implied in $26 \%$ of the cases.

Since the emergence of the Middle East respiratory syndrome coronavirus (MERS-CoV) in June 2012, 133 cases have been identified so far. All primary cases were connected to the Arabian Peninsula and nearly half of the cases died. Even though over a year has passed since the emergence of the first case, many questions on the origin and transmission patterns of the disease remain. The imminent start of the Hajj, the Muslim pilgrimage to Mecca in Saudi Arabia, in early October, is reason to review the epidemiological characteristics of the first 133 cases of MERS reported to the World Health Organization (WHO) as of 25 September 2013.

\section{Background}

The index case of the newly described MERS-CoV was detected in the Kingdom of Saudi Arabia (SA) in June 2012 [1]. Hereafter, cases and clusters of nosocomial or familial transmission were detected in nine countries in the Middle East [2-4], four in Europe [5-12] and one in Africa [13]. The virus was isolated from several cases and full sequence data are available through GenBank [14].

The reservoir and hosts of the MERS-CoV are still unknown, although virus RNA was possibly detected from bat faeces collected in the vicinity of the index case [15]. The virus belongs to the lineage $C$ of the genus of beta coronaviruses, which are genetically similar to various coronaviruses detected in bats in Africa and Europe $[16,17]$. Two studies suggest dromedary camels in Oman, the Canary Islands and Egypt may have been infected with the virus or a MERS-CoVlike virus in the past. However, human cases have not been detected in these areas $[18,19]$.

\section{Epidemiological findings as of 25 September 2013}

\section{Data collection}

This paper reviews the epidemiological characteristics of the first 133 cases of MERS, reported applying the WHO case definition, as available on the Ministry of Health $(\mathrm{MoH})$ of affected countries and WHO websites [20-24] and is based on [25]. Basic demographic data (age, sex and comorbidities) on disease severity in terms of treatment level (outpatient, hospitalised, admitted to intensive care) and information on outcomes are usually available through $\mathrm{MoH}$ websites and WHO Disease Outbreak News. Further details were collected from peer-reviewed publications and through direct communication with the SA Ministry of Health.

All data were collected contemporaneously into a line listing on MS Excel 2010 and subsequently crosschecked with existing peer-reviewed publications on cases or clusters.

For female to male ratio, case-fatality risk (CFR) and admission to an intensive care unit (ICU), we compared two time periods of transmission in 2013: March to May versus June to September, thus excluding the rather sporadic cases in 2012 and early 2013.

\section{Cases retrieved}

Between 30 March 2012 and 25 September 2013, 133 confirmed cases of MERS-CoV infections have been reported by nine countries (Figure 1). All cases have an epidemiological link to Jordan, KSA, United Arab Emirates (UAE) or Qatar. Cases detected in Europe [5-9] are linked to patients medically evacuated or seeking care in Europe. 


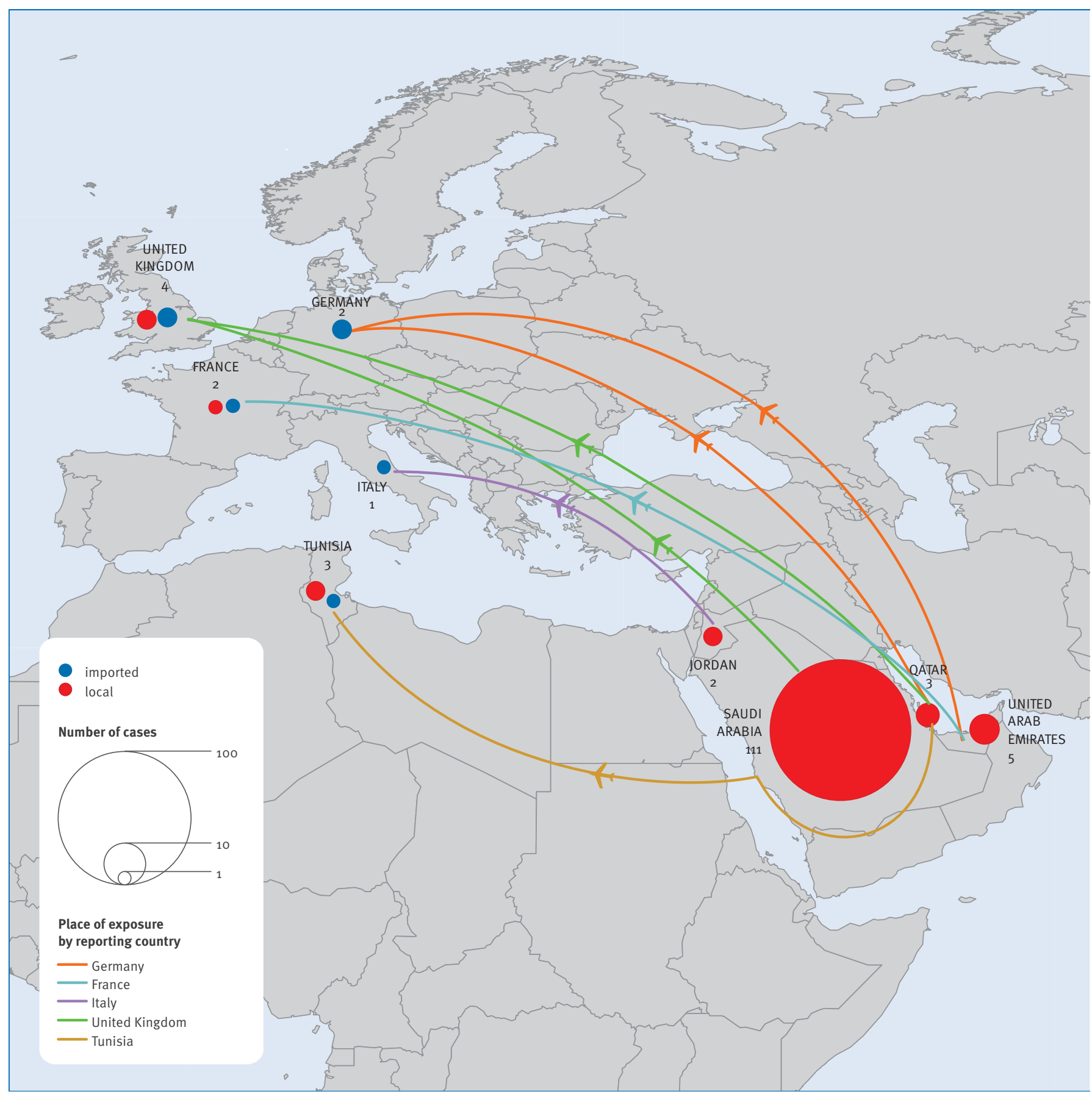

Source: [25].

MERS: Middle East respiratory syndrome.

The temporal distribution of cases suggests ongoing transmission (Figure 2).

Since June 2013,18 asymptomatic or mildly symptomatic cases have been reported. All were without any symptom or very mild with one episode of fever with or without myalgia and chills. In SA, 16 asymptomatic cases were detected during screening of all contacts of diagnosed cases and were included if positive for two specific gene targets (UpE and ORF1a) on polymerase chain reaction (PCR). The remaining two asymptomatic cases were detected in UAE.

The majority of reported cases are adult men and very few children or adolescents have been diagnosed with MERS-CoV infection (Table). The female to male ratio 


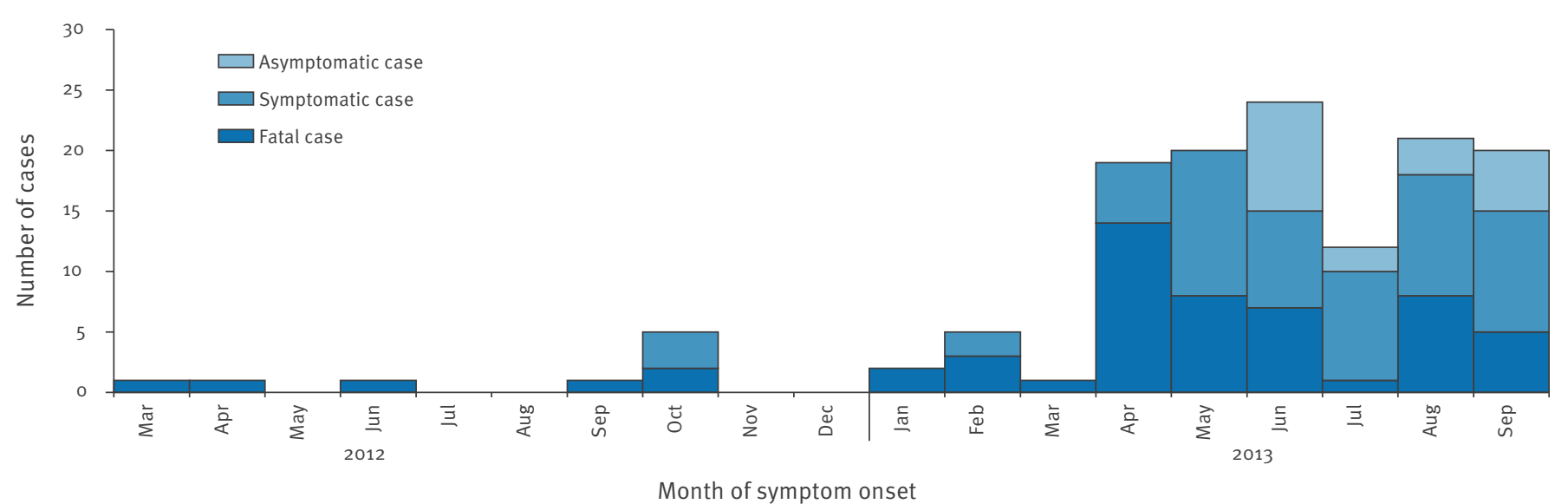

MERS: Middle East respiratory syndrome.

${ }^{a}$ Where month of onset was not available, month of reporting was used.

of cases is 0.67 overall. However, it increased in 2013 from 0.33 in March to May, to 1.08 in June to September.

We identified 14 clusters of 2-34 cases, where the primary cases were identified or suspected. However, data quality on the clusters is weak. All of the known 14 primary cases in clusters were adult men (24-83 years old) who were most likely exposed on the Arabian Peninsula. Of 129 cases with available information on transmission, 33 (26\%) were possible nosocomial transmissions, 15 of these cases were healthcare workers (HCW). Seventeen of the 23 cases reported as HCW were female.

Of all reported 133 cases, 60 (45\%) cases were admitted to intensive care (ICU). In comparison, between March and May 2013, 25 of 40 cases (63\%) were admitted to ICU, while from June to September 2013, 25 of 77 cases (33\%) were admitted to intensive care.

The overall CFR among the 133 cases is $45 \%$ on 25 September 2013. Among symptomatic cases the CFR decreased from 23 of 40 cases (58\%) in March to May to 21 of 77 (27\%) in June to September.

Men have a higher CFR compared with females ( 52 versus $24 \%$ ) (Table). Among the known primary cases in clusters with available information on outcomes, the CFR is $93 \%(13 / 14)$.

Seventy-three per cent of the 55 fatalities had at least one comorbidity reported compared to $41 \%$ of 73 surviving cases. All deaths have been reported among adults except one in a two-year-old child.

\section{Discussion}

MERS-CoV cases exposed in the Arabian Peninsula were identified in the European Union and in Tunisia mainly while seeking medical care. This has resulted in secondary transmission. The majority of travels from the Arabian Peninsula however, are destined to Asian countries which suggests that the risk of introductions exists also in Asia [26]. No cases have been reported there to date, despite enhanced surveillance in some countries. It is noteworthy that no infected cases have been detected outside the Arabian Peninsula since May 2013. The striking overrepresentation of men among cases in the first months balanced over time. This can be partly explained by the higher proportion of female HCW among recently reported nosocomial transmissions. In a similar fashion, the median age of cases has decreased.

Our assessment of the severity of the disease and outcomes is based on available data at the time of the reporting from the country and may result in under ascertainment of severe outcomes. At the same time, the proportion of cases admitted to intensive care and the CFR has decreased over time, which may be a reflection of enhanced surveillance activities.

'Superspreading' events or cases were interpreted as a key cause for the progression of the severe acute respiratory syndrome (SARS) outbreak in 2003 [27]. The large nosocomial cluster of MERS in Al Hasa, Saudi Arabia, involving up to 23 cases has some similarities with such events. It could have been caused by multiple zoonotic or human introductions in the community or inconsistencies in applying appropriate 
Distribution of confirmed MERS coronavirus cases and fatalities by age and sex, March 2012-25 September 2013 (n=128)

\begin{tabular}{|c|c|c|c|c|c|}
\hline \multirow{2}{*}{ Age range (years) } & \multicolumn{2}{|c|}{ Female } & \multicolumn{2}{|c|}{ Male } & \multirow{2}{*}{$\begin{array}{l}\text { Total number of } \\
\text { cases }\end{array}$} \\
\hline & Dead & Total & Dead & Total & \\
\hline $0-9$ & 0 & 3 & 1 & 1 & 4 \\
\hline $10-19$ & 0 & 4 & 0 & 3 & 7 \\
\hline $20-29$ & 0 & 2 & 4 & 9 & 11 \\
\hline $30-39$ & 0 & 7 & 5 & 11 & 18 \\
\hline $40-49$ & 2 & 9 & 3 & 13 & 22 \\
\hline $50-59$ & 2 & 11 & 7 & 14 & 25 \\
\hline $60-69$ & 5 & 8 & 7 & 11 & 19 \\
\hline $70-79$ & 2 & 5 & 7 & 8 & 13 \\
\hline $80-89$ & 1 & 2 & 5 & 6 & 8 \\
\hline 90-99 & 0 & 0 & 1 & 1 & 1 \\
\hline TOTAL & 12 & 51 & 40 & 77 & 128 \\
\hline Case fatality & $24 \%$ & - & $52 \%$ & - & - \\
\hline
\end{tabular}

MERS: Middle East respiratory syndrome.

a Five cases excluded due to missing age or sex data.

infection prevention measures in health facilities. It raises concerns about the 'superspreaders' as a source of extended transmission chains. The pandemic potential of MERS-CoV remains low. The basic reproduction number $\left(R_{0}\right)$ is estimated at 0.69 , lower than the $R_{0}$ for pre-pandemic SARS (o.80) and well below the epidemic threshold of 1 [28].

The significant proportion of caregivers likely infected in hospitals or at home played a role in transmission of MERS-CoV and is of concern. No secondary transmission has been associated with long-haul medical evacuation, suggesting that appropriate infection measures were applied and effective.

The fact that all but one of the primary cases in the known clusters are adult men originating from the Arabian Peninsula, suggests behavioural risk factors may play a role exposing them directly or indirectly to the reservoir of MERS-CoV. The severity of the diseases and fatal outcomes of the majority of the primary cases hinders effective exploration to identify risk factors.

Despite multiple efforts, no animal vectors or reservoirs have been identified as of yet with certainty. Exposure to camels has been reported for a few of the primary cases only.

The temporal distribution of cases suggests ongoing transmission of MERS-CoV on the Arabian Peninsula and the frequent appearance of nosocomial or familial clusters remains concerning. The number of new cases seems to have plateaued since April 2013.
Our data point towards a changing pattern of cases compared with the previously published case series [2-13] and with the review of the first 47 cases detected in SA [29]. More women and cases without comorbidities are being reported. The increased proportion of asymptomatic cases and the decreased CFR may reflect enhanced surveillance catching cases having remained unnoticed at the early stages of the epidemic.

Collaborative international efforts in the spirit of 'One health' are needed to identify the source of MERS-CoV and to describe the transmission paths into human populations on the Arabian Peninsula. With the Hajj, the Muslim pilgrimage to Mecca in Saudi Arabia, taking place in October this year and attracting 1.8 million foreign and 1.4 million domestic visitors, international public health efforts to mitigate and possibly contain this outbreak need to be reinforced. Continued vigilance in healthcare systems receiving severely ill patients with respiratory symptoms from the Arabian Peninsula is warranted.

\section{Conflict of interest}

None declared.

\section{Authors' contributions}

Pasi M.P. Penttinen, Kaja Kaasik-Aaslav, Alice Friaux, Alastair Donachie, Bertrand Sudre, Andrew J. Amato-Gauci, Ziad A. Memish and Denis Coulombier have all participated in the design of this study, data collection, data management, data analysis and writing the manuscript. 


\section{References}

1. Zaki AM, van Boheemen S, Bestebroer TM, Osterhaus AD, Fouchier RA. Isolation of a novel coronavirus from a man with pneumonia in Saudi Arabia. N Engl J Med. 2012;367(19):181420. http://dx.doi.org/10.1056/NEJMoa1211721. PMid:23075143.

2. Hijawi B, Abdallat M, Sayaydeh A, Alqasrawi S, Haddadin $A$, Jaarour $\mathrm{N}$, et al. Novel coronavirus infections in jordan, april 2012: Epidemiological findings from a retrospective investigation. East Mediterr Health J. 2013;19 Suppl 1:S12-8. PMid:23888790.

3. Memish ZA, Zumla Al, Al-Hakeem RF, Al-Rabeeah AA, Stephens GM. Family cluster of middle east respiratory syndrome coronavirus infections. N Engl J Med. 2013;368(26):2487-94 http://dx.doi.org/10.1056/NEJMoa1303729. PMid:23718156.

4. Assiri A, McGeer A, Perl TM, Price CS, Al Rabeeah AA, Cummings DA, et al. Hospital outbreak of middle east respiratory syndrome coronavirus. $\mathrm{N}$ Engl J Med. 2013;369(5):407-16. http://dx.doi.org/10.1056/ NEJMoa1306742. PMid:23782161.

5. Bermingham A, Chand MA, Brown CS, Aarons E, Tong C, Langrish C, et al. Severe respiratory illness caused by a novel coronavirus, in a patient transferred to the United Kingdom from the Middle East, September 2012. Euro Surveill. 2012;17(40):pii=20290. Available from: http://www. eurosurveillance.org/ViewArticle.aspx?Articleld $=20290$

6. The Health Protection Agency (HPA) UK Novel Coronavirus Investigation team. Evidence of person-to-person transmission within a family cluster of novel coronavirus infections, United Kingdom, February 2013 . Euro Surveill. 2013;18(11):pii=20427. Available from: http://www.eurosurveillance.org/ViewArticle. aspx?Articleld $=20427$

7. Mailles A, Blanckaert K, Chaud P, van der Werf S, Lina B, Caro V, et al. First cases of Middle East Respiratory Syndrome Coronavirus (MERS-CoV) infections in France, investigations and implications for the prevention of humanto-human transmission, France, May 2013. Euro Surveill. 2013;18(24):pii=20502. Available from: http://www. eurosurveillance.org/ViewArticle.aspx?Articleld=20502. PMid:23787161.

8. Puzelli S, Azzi A, Santini MG, Di Martino A, Facchini M, Castrucci MR, et al. Investigation of an imported case of Middle East Respiratory Syndrome Coronavirus (MERSCoV) infection in Florence, Italy, May to June 2013. Euro Surveill. 2013;18(34): pii=20564. Available from: http://www. eurosurveillance.org/ViewArticle.aspx?Articleld $=20564$. PMid:23987829.

9. Buchholz U, Müller MA, Nitsche A, Sanewski A, Wevering N, Bauer-Balci T, et al. Contact investigation of a case of human novel coronavirus infection treated in a German hospital, October-November 2012. Euro Surveill. 2013;18(8): pii=20406. Available from: http://www.eurosurveillance.org/ViewArticle. aspx?Articleld=20406. PMid:23449231.

10. Guery B, Poissy J, el Mansouf L, Sejourne C, Ettahar N, Lemaire $X$, et al. Clinical features and viral diagnosis of two cases of infection with middle east respiratory syndrome coronavirus: A report of nosocomial transmission. Lancet. 2013;381(9885):2265-72. http://dx.doi.org/10.1016/ So140-6736(13)60982-4.

11. ProMED-mail. Mers-cov- eastern mediterranean (16): Italy ex Jordan, contact cases, WHO. Archive number: 20130602.1750425, 2 Jun 2013. Available from: http://www. promedmail.org/promedprint.php?id=1750425

12. Gulland A. Two cases of novel coronavirus are confirmed in France. BMJ. 2013;346:f3114. http://dx.doi.org/10.1136/bmj. f3114. PMid:23674339.

13. Gulland A. Novel coronavirus spreads to Tunisia. BMJ. 2013;346:f3372. http://dx.doi.org/10.1136/bmj.f3372. PMid:23704132.

14. Cotten M, Watson SJ, Kellam P, Al-Rabeeah AA, Makhdoom $\mathrm{HQ}$, Assiri A, et al. Transmission and evolution of the Middle East respiratory syndrome coronavirus in Saudi Arabia: a descriptive genomic study. Lancet. 19 Sep 2013.

15. Memish ZA, Mishra N, Olival KJ, Fagbo SF, Kapoor V, Epstein $\mathrm{JH}$, et al. Middle East Respiratory Syndrome Coronavirus in Bats, Saudi Arabia. Emerg Infect Dis. 2013;19(11). http://dx.doi. org/10.3201/eid1911.131172.

16. Annan A, Baldwin HJ, Corman VM, Klose SM, Owusu M, Nkrumah EE, et al. Human betacoronavirus 2C EMC/2012. related viruses in bats, Ghana and Europe. Emerg Infect Dis. 2013;19(3):456-9. http://dx.doi.org/10.3201/eid1903.121503. PMid:23622767. PMCid:PMC 3647674.

17. Ithete N, Stoffberg S, Cottontail V, Richards L, Schoeman $M$, Drosten $C$, et al. Close relative of human Middle East respiratory syndrome coronavirus in bat, South Africa. Emerg Infect Dis. 2013;19(10):1697-9. http://dx.doi.org/10.3201/ eid1910.130946. PMid:24050621.
18. Reusken CB, Haagmans BL, Muller MA, Gutierrez C, Godeke GJ, Meyer B, et al. Middle East respiratory syndrome coronavirus neutralising serum antibodies in dromedary camels: a comparative serological study. Lancet Infect Dis. 8 Aug 2013.

19. Perera RA, Wang P, Gomaa MR, El-Shesheny R, Kandeil A, Bagato 0 , et al. Seroepidemiology for MERS coronavirus using microneutralisation and pseudoparticle virus neutralisation assays reveal a high prevalence of antibody in dromedary camels in Egypt, June 2013. Euro Surveill. 2013;18(36): $\mathrm{pii}=20574$. Available from: http://www. eurosurveillance.org/ViewArticle.aspx?Articleld=20574

20. World Health Organization (WHO). Revised interim case definition for reporting to WHO - Middle East respiratory syndrome coronavirus (MERS-CoV). Geneva: WHO. 3 Jul 2013. Available from: http://www.who.int/csr/disease/ coronavirus infections/case definition/en

21. World Health Organization (WHO). Laboratory testing for novel coronavirus - Interim recommendations. Geneva: WHO. 21 Dec 2012. Available from: http://www.who.int/csr/disease/ coronavirus_infections/LaboratoryTestingNovelCoronavirus_2 1Dec12.pdf

22. Corman VM, Müller MA, Costabel U, Timm J, Binger T, Meyer B, et al. Assays for laboratory confirmation of nove human coronavirus (hCoV-EMC) infections. Euro Surveill. 2012;17(49): pii=20334. Available from: http://www. eurosurveillance.org/ViewArticle.aspx?Articleld =20334

23. Corman VM, Eckerle I, Bleicker T, Zaki A, Landt O, EschbachBludau M, et al. Detection of a novel human coronavirus by real-time reverse-transcription polymerase chain reaction. Euro Surveill. 2012;17(39):pii=20285. Available from: http:// www.eurosurveillance.org/ViewArticle.aspx?Articleld $=20285$

24. Danielsson N, on behalf of the ECDC Internal Response Team, Catchpole M. Novel coronavirus associated with severe respiratory disease: Case definition and public health measures . Euro Surveill. 2012;17(39): pii=20282. Available from: http://www.eurosurveillance.org/ViewArticle. aspx?Articleld=20282. PMid:23041021.

25. European Centre for Disease Prevention and Control (ECDC). Rapid Risk Assessment. Severe respiratory disease associated with Middle East Respiratory Syndrome Coronavirus (MERSCoV). Seventh update, 24 September 2013. Stockholm: ECDC. Available from: http://www.ecdc.europa.eu/en/publications/ Publications/RRA_MERS-CoV_7th_update.pdf

26. Khan K, Sears J, Hu VW, Brownstein JS, Hay S, Kossowsky D, et al. Potential for the international spread of Middle East respiratory syndrome in association with mass gatherings in Saudi Arabia. PLoS Curr. 2013;5.

27. Shen Z, Ning F, Zhou W, He X, Lin C, Chin DP, et al. Superspreading SARS events, Beijing, 2003. Emerg Infect Dis. 2004;10(2):256-60. http://dx.doi.org/10.3201/eid1002.030732. PMid:15030693. PMCid:PMC3322930.

28. Breban R, Riou J, Fontanet A. Interhuman transmissibility of Middle East respiratory syndrome coronavirus: estimation of pandemic risk. Lancet. 2013;382(9893):694-9. http://dx.doi. org/10.1016/S0140-6736(13)61492-0.

29. Assiri A, Al-Tawfiq JA, Al-Rabeeah AA, Al-Rabiah FA, Al-Hajjar S, Al-Barrak A, et al. Epidemiological, demographic, and clinical characteristics of 47 cases of Middle East respiratory syndrome coronavirus disease from Saudi Arabia: a descriptive study. Lancet Infect Dis. 2013;13(9):752-61. http://dx.doi. org/10.1016/S1473-3099(13)70204-4. 